\title{
Application in deep vertical groundbeds of linear flexible anodes
}

\author{
Simone Tremolada ${ }^{1, *}$, Giorgio Martinelli ${ }^{2}$ \\ ${ }^{1}$ De Nora Italy S.r.1., 20134 Via Bistolfi,35, Milan, Italy \\ ${ }^{2}$ Industrial Cathodic Protection S.r.1., 20017 Via Risorgimento,11, Mazzo di Rho (MI), Italy
}

\begin{abstract}
This paper is about a case of application of a new anode system in a vertical groundbed in Italy for the impressed current cathodic protection of gas distribution pipelines. This system offers significant advantages for the installation of impressed current cathodic protection groundbeds with easy and timesaving procedures, accurate Quality Check on the factory-made conductive connections and optimization of the current distribution. The reduction of anode resistance versus soil enables a relevant energy saving. The product is flexible even in current output and expected design life. It is possible to select parameters, like the Mixed Metal Oxide titanium anode diameter, the feeding cable insulation, the distance and number of joints between the anode and the cable to realize a specific product fit for purpose. The reduced diameter of this anode system will enable to design new wells with consistently reduced borehole diameter. Further cost optimization can be reached by concentrating the length of the active part of the anodic system, this resulting in a reduced perforation depth. Deep Vertical Groundbed (DVG) calculations for the design of new groundbeds are presented in details with examples of a traditional string of MMO titanium anodes and linear flexible anode as alternative options.
\end{abstract}

\section{Introduction}

Linear flexible anodes were designed for the cathodic protection of pipelines, tanks (Above Surface Tanks or mounded LPG storage bullets) in soil or sand and reinforced concrete structures and had considerable success in Horizontal Directional Drilling applications.

This system is the ideal solution when the anode has to be installed very close to the structure to protect in confined spaces. The anode is assembled inside a protective sock that prevents accidental contacts with the cathode and is surrounded by calcinated petroleum coke to optimize the current distribution and to reduce the resistance at the anodesoil interface of the groundbed, either horizontal or vertical. The product core is a pure titanium wire Grade 1 according to ASTM B 863 thermally coated with mixed metal oxides of group VIII. A protective braid is offering additional mechanical resistance without interfering with the current output.

This new product offers significant advantages for the installers of impressed current cathodic protection groundbeds:

- easy and timesaving installation procedure,

- accurate QC on the factory-made conductive connections, executed leveraging on over 40 years of De Nora experience,

- optimization of the current distribution.

This is a green product, with zero discharge of pollutants in the soil. The coating consumption rate of mixed metal oxide anodes may be considered negligible with respect to the effects on the environment and can be indicated as $1 \mathrm{mg}$ per Ampere per year [1]. Moreover the reduction of anode resistance versus soil enables a relevant energy saving.

\section{Technical Specifications}

The product is flexible even in current output and expected design life (Table 1). It is possible to select parameters, like the MMO titanium anode diameter, the feeding cable insulation and cross section, the distance and number of joints between the anode and the cable to realize a specific product fit for purpose. The typical applications include cathodic protection of above ground tank bottoms with secondary containment, cathodic protection of pipelines with horizontal or vertical groundbeds or close-by cathodic protection of pipelines in congested areas of plants and cathodic protection of mounded bullets.

Table 1. Technical specifications

\begin{tabular}{|l|c|c|}
\hline Max current density & \multicolumn{2}{|c|}{$100 \mathrm{~A} / \mathrm{m}^{2}$} \\
\hline $\begin{array}{l}\text { Anodic titanium } \\
\text { wire diameter }\end{array}$ & $1,5 \mathrm{~mm}$ & $3 \mathrm{~mm}$ \\
\hline $\begin{array}{l}\text { Current output at } \\
\text { the Max current } \\
\text { density, } \mathrm{mA} / \mathrm{m}\end{array}$ & 470 & 940 \\
\hline Expected design life & & \\
\hline
\end{tabular}

\footnotetext{
* Corresponding author: simone.tremolada@denora.com
} 


\section{Case History}

I.C.P., Industrial Cathodic Protection, introduced this product for the first time in Italy, optimized for an impressed current vertical groundbed, in a $61 \mathrm{~m}$ deep vertical well, where a traditional anode was replaced. The traditional anode was a temporary solution installed to keep the deep well in operation after a major earthquake affected the region in May 2012 inducing modifications to the water table level that subsequently raised.

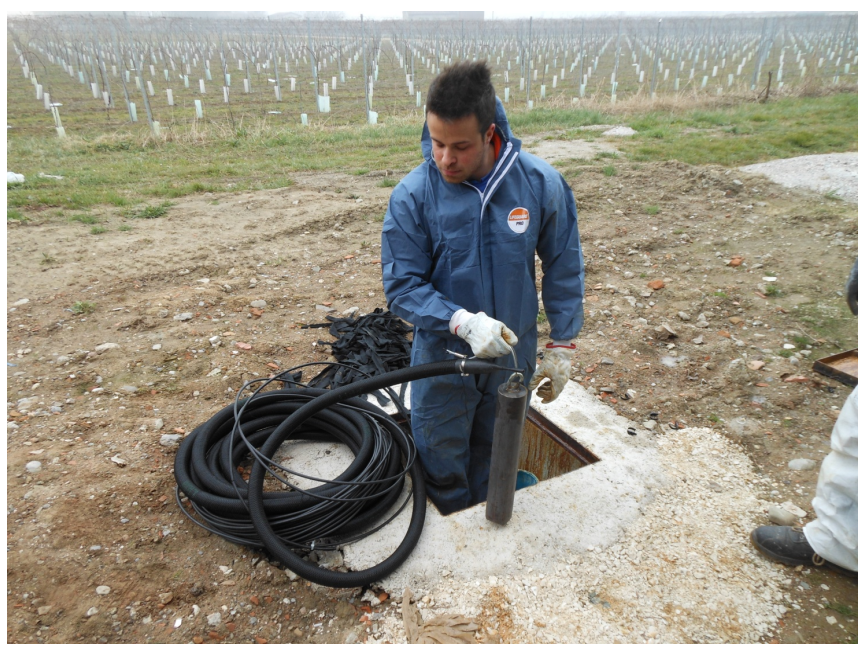

Fig. 1. Linear flexible anode before installation in deep vertical groundbed.

The active part was $15 \mathrm{~m}$ long with $3 \mathrm{~mm}$ mixed metal oxide wire anode inside. The $16 \mathrm{~mm} 2 \mathrm{PVDF} / \mathrm{HMWPE}$ cable tail was $47 \mathrm{~m}$ long.

Experience of over 40 years of groundbed installations suggested selection of a PVDF/HMWPE $1 \times 16 \mathrm{~mm} 2$ cable. This double insulation cable is resistant to environments in which hydrochloric acid and gaseous chlorine may be present. The installation was performed on March, 3rd 2015 in Northern Italy in a vertical well. The well casing was a plastic pipe with holes in the active part. The water table was located at $6 \mathrm{~m}$ depth. The anode, hanged to a dead weight, was very easily installed without the use of special tools. It was connected to a transformer rectifier equipped with a remote monitoring system.

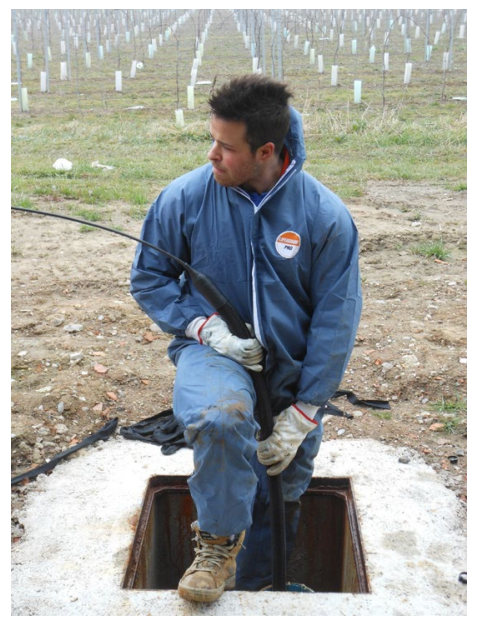

Fig. 2. Installation of linear flexible anode in deep vertical groundbed

This system allows the daily reading of minimum, medium and maximum current output and DC voltage values to monitor the evolving groundbed resistance. This data collection is aimed to assess the presence of seasonal effects on the anode performance.

Moreover the chemical analysis of the water flooding the well allows to check other parameters that can influence the anodic system durability like $\mathrm{pH}$, chloride content, and the concentration of potential pollutants like ammonia, sulfates and nitrites.

\section{Results}

As you can see in Figure 3, after the installation of the new system, it was experienced a sudden reduction of groundbed resistance $(\Omega$ Av.) from $0,95 \mathrm{Ohm}$ to $0,91 \mathrm{Ohm}$. Notably the average cell voltage (V Av.) decreased from $6,25 \mathrm{~V}$ to $5,9 \mathrm{~V}$ in the early stages and subsequently since the installation date experienced an average cell voltage increase from $5,9 \mathrm{~V}$ to 6,1 $\mathrm{V}$ and the resistance value stabilized at $0,94 \mathrm{Ohm}$. The average current output (A Av.) was stable as reported by the remote control system.

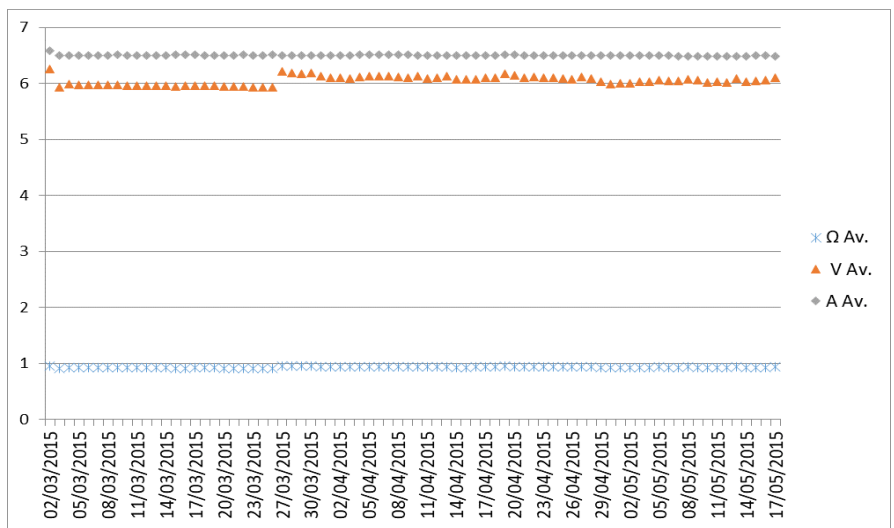

Fig. 3: Operational data of the vertical groundbed.

The test is still running with minor modifications in the groundbed structure performed to increase mechanical resistance and make that suitable for an expected lifetime of 30 years.

After this first installation more than 20 were executed in the same area and in all of them the linear anodes are still working perfectly.

\section{Other projects in Italy}

Linear anodes have now been installed in Italy for different projects. Between the more significant we need to mention the installation in 12 horizontal groundbeds for a gas distribution company in North West Italy and the cathodic protection of steel sheet piling in 2 industrial chemical plants near Milan. At the time of publication of this article all these installations are running smoothly.

\section{Design of new groundbeds}

The reduced diameter of this anode system will enable to design new wells with consistently reduced borehole diameter. This will allow big savings in the time and cost of installation. Further cost optimization can be reached by 
concentrating the length of the active part of the anodic system, this resulting in a reduced perforation depth.

\section{Deep Vertical Groundbed calculations}

\subsection{Definitions}

$\mathrm{L}$ : minimum groundbed active length $(\mathrm{m})$

$\mathrm{D}$ : hole diameter $(\mathrm{mm})$

$\mathrm{I}_{\mathrm{P}}$ : protection current $(\mathrm{A})$

$\mathrm{I}_{\mathrm{GB}}$ : Groundbed current $(\mathrm{A})$

$\mathrm{R}_{\mathrm{GB}}$ : target $\mathrm{GB}$ resistance

$\mathrm{N}_{\mathrm{A}}$ : number of anodes

$\mathrm{V}_{\mathrm{TR}}$ : maximum DC output voltage $(\mathrm{V})$

s: anode spacing $(\mathrm{m})$

\subsection{Design Calculations}

GB design current:

$$
\mathrm{I}_{\mathrm{GB}}=\mathrm{I}_{\mathrm{P}} \times \mathrm{F}
$$

with: $\mathrm{F}=1.5 \div 2$

target $\mathrm{GB}$ resistance:

$$
\begin{gathered}
\mathrm{R}_{\mathrm{GB}}=\mathrm{V}_{\mathrm{GB}} / \mathrm{I}_{\mathrm{GB}} \\
\mathrm{V}_{\mathrm{GB}}=\mathrm{V}_{\mathrm{TR}}-\mathrm{R}_{\mathrm{CABLE}} \times \mathrm{I}_{\mathrm{P}}-2 \mathrm{~V}
\end{gathered}
$$

\subsection{Example Design of DVG with Anode Strings}

Design life (DL): 25 years

- Groundbed design current $\left(\mathrm{I}_{\mathrm{GB}}\right): 12 \mathrm{~A}$

- Anode material:

- titanium mixed metal oxide coated tubular type

- suitable for installation in soil

- length, 1: $1 \mathrm{~m}$;

- diameter, d: $16 \mathrm{~mm}$;

- anode current output, $\mathrm{i}_{\mathrm{a}}: 5 \mathrm{~A}$

- Soil resistivity, $\mathrm{r}_{\text {soil }}: 20 \mathrm{ohm} . \mathrm{m}$.

- Transformer rectifier rating: $15 \mathrm{~V} / 15 \mathrm{~A}$

Assumptions

- Based on location, inactive length of groundbed is set to $46 \mathrm{~m}$, while outside concentrated area this value could be decreased, depending on soil strata.

- Hole diameter, D: $0.25 \mathrm{~m}$.

\subsection{Calculations}

\subsubsection{Anode number}

$$
\mathrm{N}=\mathrm{I}_{\mathrm{GB}} / \mathrm{i}_{\mathrm{a}}=12 \mathrm{~A} / 5 \mathrm{~A}=2.4
$$

This represents the minimum number of anodes to supply the requested protection current. Conservatively this minimum number is rounded from no. 2.4 to no. 3 anodes.

\subsubsection{Groundbed active length}

Based on maximum transformer DC output voltage (15 V) and max. Groundbed design current (12 A), groundbed resistance, $\mathrm{R}_{\mathrm{GB}}$ shall be not greater than $1.25 \mathrm{ohm}(15 \mathrm{~V} / 12 \mathrm{~A})$. Based on the above groundbed resistance, the groundbed active length - anodes + backfill - was calculated solving numerically the Dwight formula:

where:

$$
\mathrm{R}_{\mathrm{GB}}=\mathrm{r}_{\text {soil }} /(2 \pi \mathrm{L}) \mathrm{x}(\ln (8 \mathrm{~L} / \mathrm{D}-1))[3]
$$

- $\mathrm{r}_{\text {soil }}$ : soil resistivity (ohm.m);

- L: minimum groundbed active length (m);

- D: groundbed diameter $(\mathrm{m})$;

The calculated minimum groundbed active length is $13 \mathrm{~m}$.

Conservatively groundbed active length is increased to $15 \mathrm{~m}$.

\subsubsection{Anode spacing}

In calculation of actual anode spacing the parameters below listed have been used:

- anode length, $\mathrm{L}_{\mathrm{A}}$ : $1 \mathrm{~m}$

- groundbed active length, L: $15 \mathrm{~m}$

- anode number, $\mathrm{N}_{\mathrm{A}}$ : 3

The anode spacing, $\mathrm{s}$, is calculated considering that the bottom of the steel casing and at the top of the upper anodes covered with a depth of backfill equal to $\mathrm{s}$.

$$
\mathrm{s}=\left(\mathrm{L}-\mathrm{N}_{\mathrm{A}}\right) /\left(1+\mathrm{N}_{\mathrm{A}}\right)=3 \mathrm{~m}
$$

\subsection{Example Design of DVG with Flexible Anode}

Design Data

Design life (DL): 25 years

- Groundbed design current $\left(\mathrm{I}_{\mathrm{GB}}\right): 12 \mathrm{~A}$

- Anode material:

- Mixed metal oxide coated titanium wire anode type suitable for installation in soil

- length, 1: $15 \mathrm{~m}$

- diameter, d: $3 \mathrm{~mm}$

- anode current output, $\mathrm{i}_{\mathrm{a}}$ : $15 \mathrm{~A}$

- Soil resistivity, r: 20 ohm.m.

- Transformer rectifier rating: $15 \mathrm{~V} / 15 \mathrm{~A}$

\subsection{Calculations}

\subsubsection{Anode length}

The maximum linear anode current output is $940 \mathrm{~mA} / \mathrm{m}$ at $100 \mathrm{~A} / \mathrm{m} 2$ current density. Therefore the minimum required length of the anode is $12 / 0.940=12.8 \mathrm{~m}$, conservatively this minimum length is rounded to $15 \mathrm{~m} .7 .4 .2$ Groundbed

\subsubsection{Groundbed active length}

Based on maximum transformer DC output voltage (15 V) and max. Groundbed design current (12 A), groundbed resistance, $R_{\mathrm{GB}}$ shall be not greater than $1.25 \mathrm{ohm}(15 \mathrm{~V} / 12 \mathrm{~A})$. Based on the above groundbed resistance, the groundbed active length - anodes + backfill - was calculated solving numerically the Dwight formula:

where:

$$
\mathrm{R}_{\mathrm{GB}}=\mathrm{r}_{\mathrm{soil}} /(2 \pi \mathrm{L}) \mathrm{x}(\ln (8 \mathrm{~L} / \mathrm{D}-1))
$$

- $\mathrm{r}_{\text {soill }}$ soil resistivity (ohm.m);

- L: minimum groundbed active length (m);

- D: groundbed diameter $(\mathrm{m})$;

The calculated minimum groundbed active length is $12 \mathrm{~m}$, conservatively groundbed active length is increased to $15 \mathrm{~m}$. 


\section{Conclusions}

Linear flexible anode if properly designed can be an effective solution for the replacement of existing anodes in deep well groundbeds. Installation of the linear flexible anodic system was fast and easy without the use of special tools. The average cell voltage and groundbed were initially lower than experienced with the previous anodic system and remained stable during the test. Selecting this system since the beginning it's possible to design new groundbeds with reduced borehole diameter and perforation depth.

\section{References}

1. W. Von Baeckmann, W.Schwenk and Prinz, Handbook of Cathodic Corrosion Protection, Theory and Practice of Electrochemical Protection Process, Gulf Professional Publishing (1997)

2. A.W. Peabody, Peabody's Control of Pipeline Corrosion, NACE International (2001)

3. L. Lazzari, P. Pedeferri, Cathodic Protection, Polipress (2006) 